\title{
Biomedical Science
}

No. 1

Review

1 Water-Insoluble Camptothecin Analogues as Potential Antivira Drugs

Pantazis, P.; Han, Z.; Chatterjee, D.; Wyche, J. (Providence, R.I.)

Original Papers

8 Heterologous Gene Expression in Avian Cells: Potential as a Producer of Recombinant Proteins

Lee, S.Y.; Kim, S.H.; Kim, V.N. (Seoul); Hwang, J.H. (Kyung-Ki-Do); Jin, M. Lee, J. (Kyunggido); Kim, S.Y. (Seoul)

18 A Pstl Polymorphism Detects the Mutation of Serine ${ }_{128}$ to Arginine in CD 62E Gene - a Risk Factor for Coronary Artery Disease

Ye, S.Q. (Baltimore, Md.); Usher, D. (Newark, Del.); Virgil, D.; Zhang, L.Q.; Yochim, S.E.; Gupta, R. (Baltimore, Md.)

22 Acute Exercise Enhances Receptor-Mediated EndotheliumDependent Vasodilation by Receptor Upregulation Cheng, L.J. (Kaohsiung); Yang, C.C.; Hsu, L.Y.; Lin, M.T.; Jen, C.J.; Chen, H. (Tainan)

28 Effects of Nitric Oxide Synthase Inhibitors on Systemic Hypotension, Cytokines and Inducible Nitric Oxide Synthase Expression and Lung Injury following Endotoxin

Administration in Rats

Wang, D.; Wei, J.; Hsu, K.; Jau, J..C.; Lieu, M.-W.; Chao, T.J. (Taipei) Chen, H.I. (Hualien)

36 Effect of Excitatory Amino Acid Neurotransmitters on Acid Secretion in the Rat Stomach

Tsai, L.H.; Lee, Y.J. (Taipei); Wu, J.Y. (Lawrence, Kans.)

45 Activation of a Cryptic Splice Donor in Human Immunodeficiency Virus Type-1

Borg, K.M.; Favaro, J.P.; Arrigo, S.J.; Schmidt, M. (Charleston, S.C.)

53 Peptide Loading in the Endoplasmic Reticulum Accelerates Trafficking of Peptide: MHC Class II Complexes in B Cells Morkowski, S. (Seattle, Wash.); Raposo, G.; Geuze, H.J. (Utrecht); Rudensky, A.Y. (Seattle, Wash.)

64 Expression of Foreign Antigens on the Surface of Escherichia coli by Fusion to the Outer Membrane Protein TraT Chang, H.H.; Sheu, S.Y.; Lo, S.J. (Taipei)
No. 2

Reviews

71 Recent Advances in Understanding Thyroid Hormone Receptor Coregulators

Lee, H.J. (Taiwan); Yen, P.M. (Bethesda, Md.)

79 Trophic Interactions between Sensory Nerves and Their Targets Chen, W.P.; Chang, Y.C.; Hsieh, S.T. (Taipei)

Original Papers

86 Anticonvulsants for Soman-Induced Seizure Activity Shih, T.M.; McDonough, J.H., Jr.; Koplovitz, I. (Aberdeen Proving Ground, Md.)

97 Activation of Muscarinic Receptors in Porcine Airway Smooth Muscle Elicits a Transient Increase in Phospholipase D Activity Mamoon, A.M.; Smith, J.; Baker, R.C.; Farley, J.M. (Jackson, Miss.)

106 Amino Acid Conservation and Clinical Severity of Human Glucose-6-Phosphate Dehydrogenase Mutations Cheng, Y.S.; Tang, T.K.; Hwang, M.J. (Taipei)

115 Isolation of Full-Length cDNA and Chromosomal Localization of Human NF-kB Modulator NEMO to Xq28

Jin, D.Y.; Jeang, K.T. (Bethesda, Md.)

121 The Fidelity of Reverse Transcription Differs in Reactions Primed with RNA versus DNA Primers Oude Essink, B.B.; Berkhout, B. (Amsterdam)

133 Studies on the Mechanisms Responsible for Inhibition of Experimental Metastasis of B16-F10 Murine Melanoma by Pentoxifylline

Gude, R.P. (Mumbai); Binda, M.M.; López Presas, H. (Buenos Aires); Klein-Szanto, A.J.P. (Philadelphia, Pa.); Bonfil, R.D. (Buenos Aires)

Short Communication

142 Antitumor Effects of IL-6 on Murine Liver Tumor Cells in vivo Kang, H.S.; Cho, D.H. (Taejon); Kim, S.S. (Ulsan); Pyun, K.H.; Choi, I. (Taejon)

\section{KARGER}

Fax + 41613061234 E-Mail karger@karger.ch www.karger.com
(C) 1999 S. Karger AG, Basel

Access to full text and tables of contents, including tentative ones for forthcoming issues: www.karger.com/journals/jbs/jbs_bk.htm 
No. 3

Reviews

145 'Genomics': Buzzword or Reality?

Jordan, B.R. (Marseille)

151 Selenocysteine-Containing Proteins in Mammals Gladyshev, V.N. (Lincoln, Nebr.); Hatfield, D.L. (Bethesda, Md.)

Original Papers

161 On the Mechanism of Cesium-Induced Voltage and Current Tails in Single Ventricular Myocytes

Shen, J.B.; Vassalle, M. (Brooklyn, N.Y.)

176 Muscarinic Activation Causes Biphasic Inotropic Response and Decreases Cellular $\mathrm{Na}^{+}$Activity in Canine Cardiac Purkinje Fibers

Yang, J.M.; Chung, K.T.; Yang, S.T.; Yang, S.N. (Taipei)

183 Effects of Serotonin Depletion by $p$-Chlorophenylalanine, p-Chloroamphetamine or 5,7-Dihydroxytryptamine on Central Dopaminergic Neurons: Focus on Tuberoinfundibular Dopaminergic Neurons and Serum Prolactin Yang, I.C.H.; Pan, J.T. (Taipei)

194 HIV-1 Rev Promotes the Nuclear Export of Unspliced and Singly Spliced RNAs in a Mammalian Cell-Free Export System Huffman, K.M.; Arrigo, S.J.; Schmidt, M.G. (Charleston, S.C.)

206 Analysis of Potential Phosphorylation Sites in Human T Cell Leukemia Virus Type 1 Tax

Krause Boehm, A. (Charlottesville, Va./Omaha, Nebr.); Stawhecker, J.A.; Semmes, O.J.; Jankowski, P.E. (Charlottesville, Va.); Lewis, R. (Omaha, Nebr.); Hinrichs, S.H. (Charlottesville, Va.)

213 Sodium Vanadate Inhibits Apoptosis in Malignant Glioma Cells: A Role for Akt/PKB

Chin, L.S.; Murray, S.F.; Harter, D.H.; Doherty, P.F.; Singh, S.K (Baltimore, Md.)
No. 4

219 Biomedical Vignette

Reviews

220 GB Virus-C/Hepatitis G Virus Infection in Taiwan: A Virus That Fails to Cause a Disease?

Kao, J.H.; Chen, D.S. (Taipei)

226 The Isoprostanes: Novel Prostaglandin-Like Products of the Free Radical-Catalyzed Peroxidation of Arachidonic Acid Liu, T. (Kaohsiung); Stern, A. (New York, N.Y.); Roberts, L.J.; Morrow, J.D. (Nashville, Tenn.)

236 Anticancer Drug Design Based on Plant-Derived Natural Products Lee, K.H. (Chapel Hill, N.C.,)

Original Papers

251 Sensitivity of the Slow Component of the Delayed Rectifier Potassium Current $\left(\mathrm{I}_{\mathrm{Ks}}\right)$ to Potassium Channel Blockers: Implications for Clinical Reverse Use-Dependent Effects Lai, L.P.; Su, M.J.; Tseng, Y.Z.; Lien, W.P. (Taipei)

260 The Various Effects of Fractionated Oxidized Low Density Lipoproteins on the Growth of Smooth Muscle Cells in Culture Lin, M.T.; Su, W.C.; Cheng, M.L.; Cheng, K.S.; Chang, W.C.; Wing, L.Y.C.; Jen, C.J.; Wu, H.L. (Tainan)

269 Modulation of Cytokine Responses of Murine CD8+ $\alpha \beta$ Intestinal Intraepithelial Lymphocytes by IL-4 and IL-12 Gelfanova, V.; Lai, Y.G.; Gelfanov, V.; Tzou, S.C.; Tu, Y.F.; Liao, N.S (Taipei)

277 Probing Surface Structure of Sarcin Domain on Ribosomes of Escherichia coli by Complementary Oligo DNAs and Ribosome-Inactivating Protein Cheung, J.I.; Lin, A. (Taipei)

285 The Tumor Suppressor p53 Can Reduce Stable Transfection in the Presence of Irradiation

Lee, H. (Sudbury); Sun, D. (Richmond, Va.); Larner, J.M.

(Charlottesville, Va.); Wu, F.S. (Richmond, Va.)

Short Communication

293 The Role of Protein Kinase $\mathbf{C}$ in Thromboxane $A_{2}$-Induced Pulmonary Artery Vasoconstriction Murtha, Y.M.; Allen, B.M.; Orr, J.A. (Lawrence, Kans.)

296 Book Review 
Reviews

298 HIV-1 Evolution under Pressure of Protease Inhibitors: Climbing the Stairs of Viral Fitness Berkhout, B. (Amsterdam)

306 Hypothesis: A Recurrent, Moderate Activation Fosters Systemic Autoimmunity - The Apoptotic Roles of TCR, IL-2 and Fas Ligand

Matsui, K.; Jodo, S.; Xiao, S.; Ju, S.T. (Boston, Mass.)

314 Signal Transduction Pathway for Anterior-Posterior Development in Drosophila Baek, K.H.; Lee, K.Y. (Boston, Mass.)

\section{Original Papers}

320 Purification of RBF-2, a Transcription Factor with Specificity for the Most Conserved cis-Element of Naturally Occurring HIV-1 LTRs

Estable, M.C.; Hirst, M.; Bell, B.; O’Shaughnessy, M.V.; Sadowski, I. (Vancouver)

333 Organization of HIV-1 pol Is Critical for Pol Polyprotein Processing

Chang, Y.C.; Yu, S.L.; Syu, W.J. (Taipei)

342 Systematic Comparison of a Color Reporter Gene and Drug Resistance Genes for the Determination of Retroviral Titers Sapp, Ch.M.; Li, T.; Zhang, J. (Lexington, Ky.)

349 Propionibacterium acnes Induces Acute TNF $\alpha$-Mediated Apoptosis of Hepatocytes Followed by Inflammatory T-Cell-Mediated Granulomatous Hepatitis in Mice Chen, Y.L.; Yu, C.K.; Lei, H.Y. (Tainan)

357 A Nontoxic Pseudomonas Exotoxin A Induces Active Immunity and Passive Protective Antibody against Pseudomonas Exotoxin A Intoxication

Chen, T.Y.; Lin, C.P.; Loa, C.C.; Chen, T.L.; Shang, H.F.; Hwang, J.; Hui, C.F. (Taipei)

364 Book Review
367 Editoria

Review

368 Looking Back on the Discovery of $\alpha$-Bungarotoxin Chang, C.C. (Taipei)

Original Papers

376 Ionic Mechanisms for the Antiarrhythmic Action of Cinnamophilin in Rat Heart

Su, M.J.; Chen, W.P.; Lo, T.Y. (Taipei); Wu, T.S. (Tainan)

387 Positive Inotropic Action of NMDA Receptor Antagonist $(+)-M K 801$ in Rat Heart

Huang, C.F.; Su, M.J. (Taipei)

399 Reentrant Tachyarrhythmias in Right Atria of Cardiomyopathic versus Healthy Syrian Hamster

Lin, C.I.; Yiu, M.Y.; Hwang, H.R.; Lin, C.L.; Chen, K.Y. (Taipei)

409 Involvement of Mitogen-Activated Protein Kinase in Hippocampal Long-Term Potentiation

Wu, S.P.; Lu, K.T.; Chang, W.C.; Gean, P.W. (Tainan City)

418 Involvement of Apamin-Sensitive SK Channels in Spike Frequency Adaptation of Neurons in Nucleus tractus solitarii of the Rat

Yen, J.C.; Chan, J.Y.H.; Chan, S.H.H. (Taiwan)

425 Potentiation of Lipopolysaccharide-Induced IL-6 Release by Uridine Triphosphate in Macrophages: Cross-Interaction with Cyclooxygenase-2-Dependent Prostaglandin $\mathrm{E}_{2}$ Production Chen, B.C.; Lin, W.W. (Taipei)

433 Kynostatin and $17 \beta$-Estradiol Prevent the Apoptotic Death of Human Neuroblastoma Cells Exposed to HIV-1 Protease Hawkins, V.; Shen, Q.; Chiueh, C.C. (Bethesda, Md.)

439 Author Index Vol. 6, 1999

440 Subject Index Vol. 6, 1999
S. Karger

Medical and Scientific Publishers Basel $\cdot$ Freiburg $\cdot$ Paris $\cdot$ London

New York $\cdot$ New Delhi $\cdot$ Bangkok

Singapore $\cdot$ Tokyo $\cdot$ Sydney
Drug Dosage

The authors and the publisher have exerted every effort to ensure that drug selection and dosage set forth in this text are in accord with current recommendations and practice at the time of publication. However, in view of ongoing research, changes in government regulations, and the constant flow of informaion relating to drug ion relating to drug therapy and drug reactions, the reader is urged to check the package insert for each drug for any change in indications and dosage and for added warnings and precautions. This is particularly important when the recommended agent is a new and/or infrequently employed drug.
All rights reserved.

No part of this publication may be translated into other languages, reproduced or utilized in any form or by any means, electronic or mechanical, including photocopying, recording, microcopying, or by any information storage and retrieval system, without permission in writing from the publisher or, in pect of a specified fee the Copyright Clearance Center (see 'General Information').

(c) Copyright 1999 by S. Karger AG,

P.O. Box, CH-4009 Basel (Switzerland)

Printed in Switzerland on acid-free paper by

Reinhardt Druck, Basel 